\title{
PHYSIOLOGICAL CHANGES IN SEEDS AND SEEDLINGS OF PUMPKINS SUBMITTED TO SALT STRESS
}

\author{
ALTERAÇÕES FISIOLÓGICAS EM SEMENTES E MUDAS DE ABÓBORAS \\ SUBMETIDAS A ESTRESSE SALINO
}

\author{
Bárbara França DANTAS ${ }^{\text {; Janete Rodrigues MATIAS }}{ }^{1}$; Armando Pereira LOPES$^{2}$; \\ Carlos Alberto ARAGÃO ${ }^{2}$ \\ 1. Embrapa Semiárido, Petrolina, PE, Brasil. barbara.dantas@embrapa.br; 2. Universidade do Estado da Bahia-UNEB, Juazeiro, BA, \\ Brasil.
}

\begin{abstract}
Salinity is one of the most limiting environmental factors for plant growth in semi-arid regions. Excess of salts reduces water potential, causes physiological drought and can influence germination and initial growth of plants. The objective of this work was to study physiological and metabolic changes in seeds and seedlings of pumpkin (Cucurbita pepo cultivars Caserta and Redonda and C. maxima cv. Coroa) in a saline condition of salt stress. Thus, we it was quantified germination parameters; seedlings growth; seeds and seedlings respiration; degradation of total soluble sugars, reducing sugars and total proteins in cotyledons and the activity ascorbate peroxidase (APX), glutathione-S-transferase (GST) and catalase (CAT) during germination and initial growth of the pumpkin species studied in saline conditions. The experimental design was totally randomized in a factorial scheme $6 \times 3$, with six electrical conductivities $\left(0 ; 2 ; 4 ; 6 ; 8\right.$ e $\left.10 \mathrm{dS}^{-1} \mathrm{~m}^{-1}\right)$ and three cultivars (Redonda, Caserta and Coroa). Salinity did not influence the rate of seed respiration during the germination, although seedlings respiration decreased, as well as its vigour. Total sugars were degraded, while there was accumulation of reducing sugars and proteins in cotyledons of germinating seeds in salt solutions. Increased electrical conductivity reduced APX activity in the embryo and CAT in cotyledons, but did not influence GST. Pumpkin seedlings showed low tolerance to salt stress.
\end{abstract}

KEYWORDS: Vigour. Seedlings. Electrical conductivity. Cucurbita pepo. Cucurbita maxima.

\section{INTRODUCTION}

The Cucurbitaceae family occurs in most tropical regions of the world and consists of about 120 genera that contain more than 800 species. Among the economically important cucurbits are pumpkins Cucurbita pepo L. and Cucurbita maxima L. (RESENDE et al., 2013). The world production of pumpkins (Cucurbita spp.) has reached 24 million tonnes in approximately 1.8 million hectares planted (FAO, 2017). In Brazil, pumpkins stand out among the Cucurbitaceae, due to their high socioeconomic and food importance in different regions (FERREIRA et al., 2006). They are widely cultivated in the Brazilian Northeast, a region with great vulnerability to adverse environmental conditions and one of the Brazilian regions most likely to be affected by climate change, with increasing temperature, drought and soil salinization (MARENGO, 2014).

These harsh environmental conditions influence germination, as well as the growth and development of plants. When any of these exceeds the seed's tolerance, it results in stress, which in turn affects its developmental, structural, physiological and biochemical processes (TUTEJA et al., 2009). The ability of seeds to germinate under adverse conditions is defined as a manifestation of vigour and depends amongst other factors, on environmental conditions found at the location where seeds were sown (FARAHANI; MAROUFI, 2011).

Soils with low humidity or saline environments may result in water restrictions that compromise seed germination and initial growth of seedlings. Under saline conditions, the water potential in the substrate decreases, impeding water absorption by seeds (ARZANI, 2008). Therefore, essential cellular processes required for germination, such as cell division and elongation, and mobilisation of reserves are also affected (SOLTANI et al., 2006).

Drought, salinity, extreme temperatures, and oxidative metabolism are interrelated and may induce similar cellular damages, leading to oxidative stress (LI et al., 2014). This stress causes denaturation of soluble proteins and loss of the enzymatic function (LI et al., 2014). Furthermore, oxidative stress due to salt stress leads to a serious imbalance between the production of reactive oxygen species (ROS) and antioxidant defense. Consequently, these diverse environmental stresses 
frequently activate signalling pathways and similar responses in cells, such as production of anti-stress proteins, regulation of antioxidants, and accumulation of compatible solutes (CAVERZAN, 2008).

Respiration of seeds during salt stress has been reported to affect seedling development (MOUD; MAGHSOUDI, 2008). The excess of ROS, which can also be produced by respiration during germination, can cause rapid cell damage by triggering an oxidative chain reaction (AHMAD et al., 2010). The toxic effects of ROS are counteracted by antioxidant enzymes, catalase-CAT (BREUSEGEM et al., 2001), ascorbate peroxidaseAPX (GILL; TUTEJA, 2010), glutathione-Stransferase-GST (SECKIN et al., 2010).

Due to geological formation soils and groundwater of the Brazilian Northeast are salinized. Thus, to evaluate the seed responses of the most cultivated varieties of pumpkins in the region regarding saline stress, the objective of this study was to evaluate possible physiological and metabolic changes in seeds and seedlings of pumpkin (Cucurbita pepo cultivars Caserta and Redonda and C. maxima cv. Coroa) in salt solutions.

\section{MATERIAL AND METHODS}

Seeds of C. pepo cv. Caserta and cv. Redonda, as well as, $C$. maxima cv. Coroa were obtained from local seed commercialising markets at Petrolina, Pernambuco State, Brazil. These were stored in a cold chamber $\left(10 \pm 2{ }^{\circ} \mathrm{C}\right.$; $\left.\mathrm{RH} 40 \pm 5 \%\right)$ during six months until the beginning of the trials.

The seeds were subjected to germination tests by using germitest paper moistened with $\mathrm{NaCl}$ solution at 2.5 times their weight prepared in the following electrical conductivities: $0,2,4,6,8$, and $10 \mathrm{dS} \mathrm{m}^{-1}$ (RICHARDS, 1974), corresponding to an osmotic potential of 0 to $-0.36 \mathrm{MPa}$. Subsequently, the seeds were maintained in a Biochemical Oxygen Demand (BOD) incubator at $25^{\circ} \mathrm{C}$ with a photoperiod of $12 \mathrm{~h}$ for 8 days (BRASIL, 2009).

Germination was assessed daily to determine the percentage of germinated seeds (seedlings displaying 2-mm-long radicles) and calculate the average germination time (AGT), average germination speed (AGS), and germination speed index (GSI) (RANAL; SANTANA, 2006). Eight days after sowing, the percentage of normal and abnormal seedlings was determined (BRASIL, 2009). The lengths of shoots and roots length of normal seedlings were measured (CARVALHO; NAKAGAWA, 2012). This trial was performed using complete randomised block design and $6 \times 3$ (electrical conductivities $\times$ genotypes) factorial scheme with four replicates of 50 seeds, to assess germination (AGT, AGS, GSI, normal and abnormal seedlings), and four replicates of 10 seedlings, to assess vigour (shoot and root length).

Water uptake and respiration by seeds during germination were evaluated in an independent assay only for $C$. pepo cv. Caserta and C. maxima cv. Coroa. The trials were performed in two electrical conductivities (EC) with two replicates of 100 seeds sown in gerboxes containing two sheets of germitest paper moistened with 2.5 times their weight of distilled water $\left(\mathrm{EC}=0 \mathrm{dS} \mathrm{m}^{-1}\right)$ or $\mathrm{NaCl}$ solution $\left(\mathrm{EC}=4 \mathrm{dS} \mathrm{m}^{-1}\right)$. Seeds were placed in a BOD incubator at $25^{\circ} \mathrm{C}$ with a photoperiod of $12 \mathrm{~h}$, during 96 hours. The evaluations were performed after $0,4,8,24,48,72$, and $96 \mathrm{~h}$ after sowing. Water uptake was evaluated by weighing seeds before and after each time span of soaking and was expressed in volume of water imbibed (SILVA; DANTAS, 2016).

Seed respiration during germination was assessed by measuring $\mathrm{CO}_{2}$ release of seeds using an infrared gas analyser IRGA LI-6200 model (Li-Cor, Lincoln, NE, USA) connected to a 2-litre chamber. During each evaluation seeds were placed in the IRGA chamber during five minutes to allow gas exchange and increase of $\mathrm{CO}_{2}$ inside the chamber. Seeds respiration was expressed by $\mathrm{CO}_{2}$ concentration (mmol) in the chamber per seeds weight $(\mathrm{g})$ measured during five minutes (DANTAS et al., 2015).

In order to evaluate degradation and mobilization of seed reserves during the germination, cotyledons of 100 seedlings from the germination test were collected at 1,2 , and 4 days after sowing. Crude extracts were obtained by maceration of $1.0 \mathrm{~g}$ of fresh cotyledons with a mortar and pestle in $10 \mathrm{~mL}$ of $100 \mathrm{mM}$ potassium phosphate buffer, $\mathrm{pH} 7.0$, and centrifuging at 10.000 $\times g$ for $10 \mathrm{~min}$. The supernatant (crude extract) was stored in microtubes at $-20^{\circ} \mathrm{C}$ for quantification of total proteins total soluble sugars, and reducing sugars (RIBEIRO et al., 2012). Four days after sowing seeds in saline solutions, the cotyledon and embryonic axis of 100 seedlings were collected to extract and quantify the enzyme activity of ascorbate peroxidase (APX, enzyme commission 1.11.1.11), catalase (CAT, enzyme commission 1.11.1.6) and glutathione-S-transferase (GST, enzyme commission 2.5.1.18), according to the methodology described by Ribeiro et al. (2014).

Data regarding germination and vigour were subjected to a polynomial regression analysis in the statistical program SISVAR, whereas data regarding 
the biochemical analysis and respiration were plotted using line graphs and mean standard error bars.

\section{RESULTS AND DISCUSSION}

The initial germination of the non-stressed seeds ranged from $59 \%$ to $70 \%$ (Figure 1) indicating that the seed lots did not show high quality. Although seeds were thought to be obtained with high quality, after only six month storage at appropriate conditions $\left(10 \pm 2{ }^{\circ} \mathrm{C}\right.$; $\left.\mathrm{RH} 40 \pm 5 \%\right)$, these did not show best potential physiological quality, wich might have influenced in their response to salinity. As the electrical conductivity of the

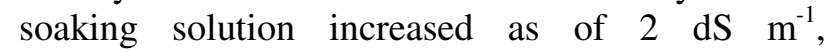
germination (\% of normal seedlings) of all cultivars decreased and the percentage of abnormal seedlings increased (Figure 1). The germination of seeds of $C$. pepo cv. Redonda, which had the lowest vigour, around $60 \%$ of germination in distilled water, decreased drastically with increasing electrical conductivity. Thus, only $20 \%$ of normal seedlings of $\mathrm{cv}$. Redonda developed at $2 \mathrm{dS} \mathrm{m^{-1 }}$ thus they didn't show fitted regression curves (Figure 1, A-D).

Similar to the results in this study, a reduction in osmotic potential of the substrate caused by $\mathrm{NaCl}$ solution impaired seed germination and development of seedlings in other cucurbits such as watermelon (TORRES, 2007; DANTAS et al., 2015; SILVA et al., 2015), melon (ARAGÃO et al., 2009; SECCO, 2010), and cucumber (MATIAS et al., 2015).

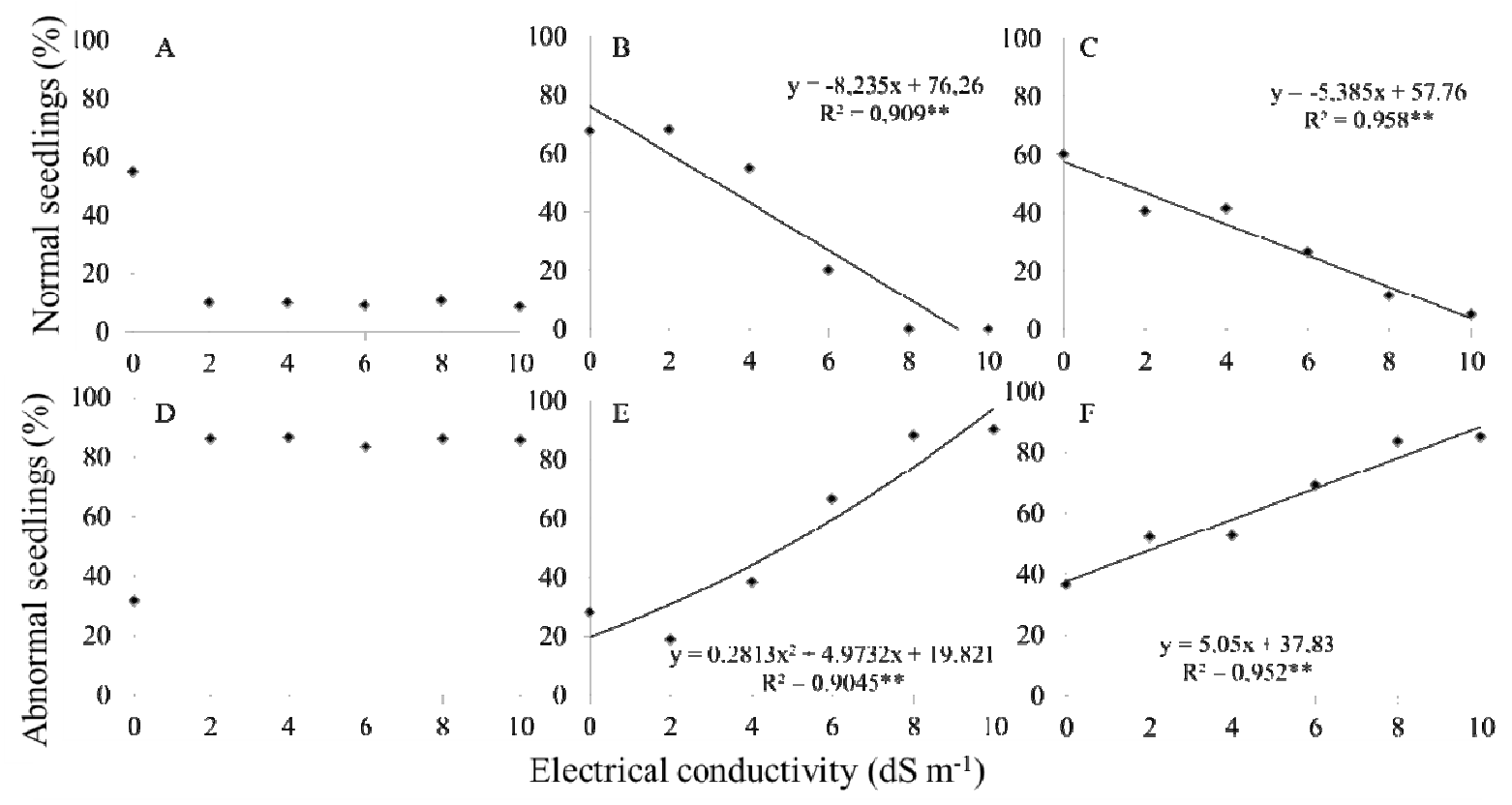

Figure 1. Normal and abnormal seedlings of three pumpkin cultivars (A, D- Redonda; B, E - Coroa; C, F Caserta.) germinated in different electrical conductivities of $\mathrm{NaCl}$ solutions.

Average germination time (AGT), average germination speed (AGS) and germination speed index (GSI) all indicate the speed of germination of seeds and showed similar results (Figure 2). In all pumpkin cultivars, the increasing of salt stress led to germination speed decrease (Figure 2). However, only the seeds of $C$. pepo cv. Redonda were greatly affected by the increasing electrical conductivity, with an increase in AGT from 2 to 3 days. This was also observed in cv. Caserta and Coroa seeds, although, the AGT was around 2 days (Figure 2DE). The same was observed for AGS and GSI (Figure 2A-C, G-I). 

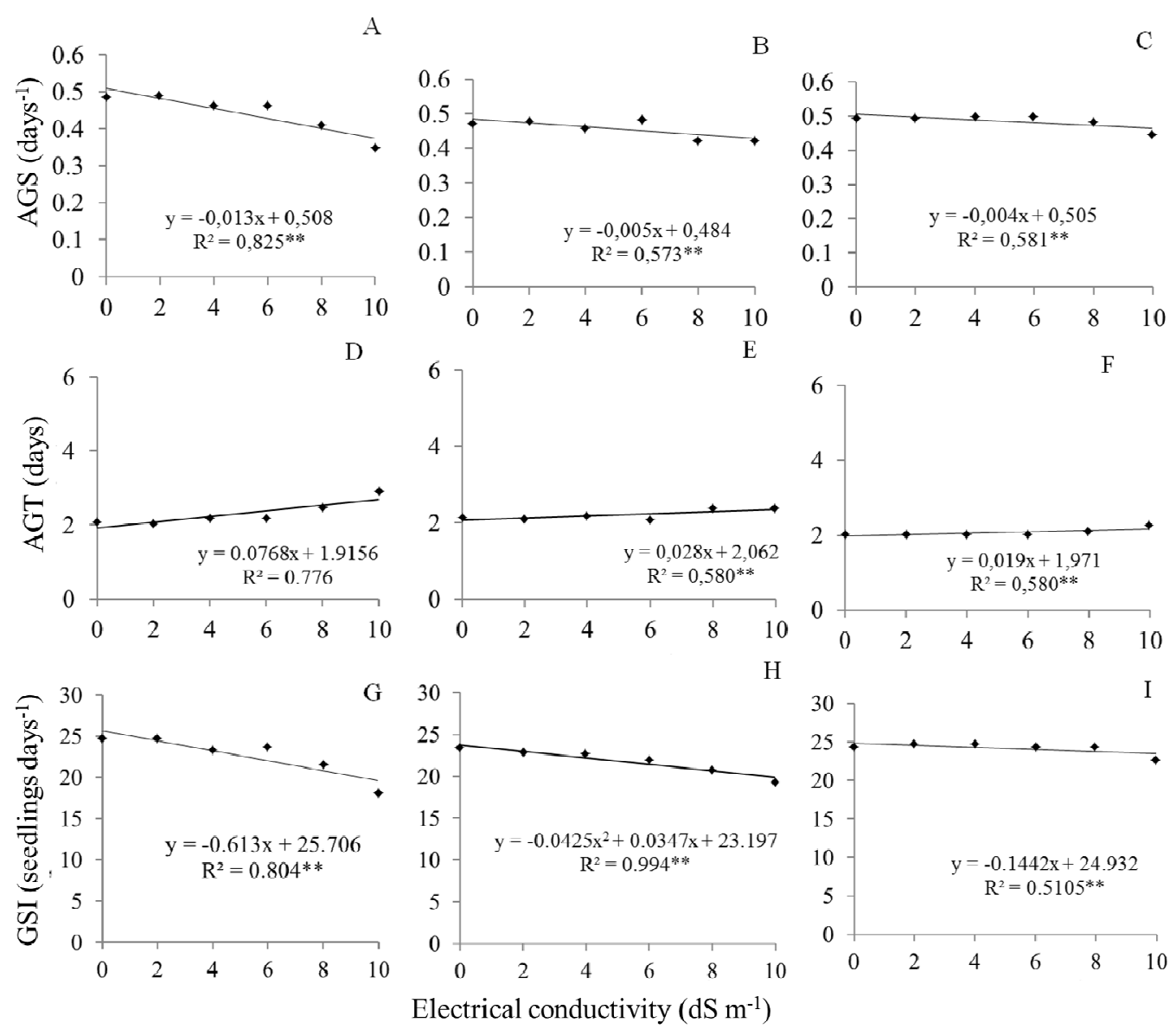

Figure 2. Average germination speed (AGS), average germination time (AGT) and germination speed index (GSI) of three pumpkin cultivars (A, D, G-Redonda; B, E, H- Coroa; C, F, I-Caserta) germinated in different electrical conductivities of $\mathrm{NaCl}$ solutions.

The increase of salt concentration in the substrate reduces water potential, resulting in a lower ability of seeds to uptake water, which generally influences germination capacity and seedling development (CARVALHO; NAKAGAWA, 2012). Besides promoting the development of abnormal seedlings (Figure 1), the gradual increase salt concentration also induced a reduction of the shoot length of all cultivars and a reduction of root length for $\mathrm{cv}$. Coroa and $\mathrm{cv}$. Caserta (Figure 3). Root length results of cv. Redonda were not affected by electrical conductivity of up to $10 \mathrm{dS} \mathrm{m}{ }^{-1}$ thus they didn't show fitted regression curves (Figure 3A).

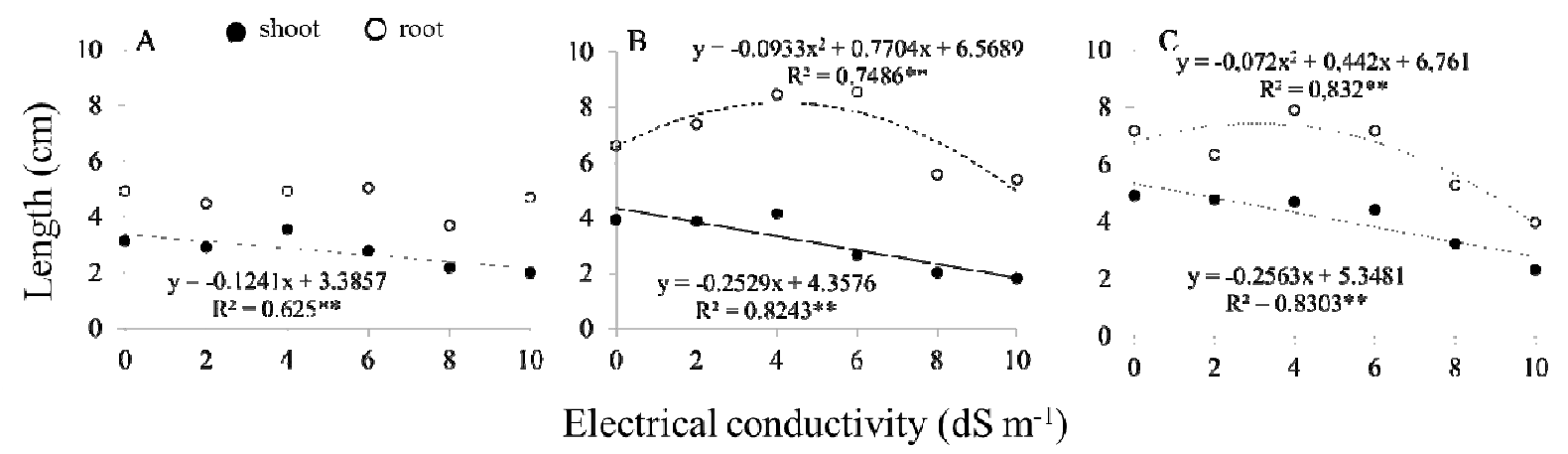

Figure 3. Shoot and root length of three pumpkin cultivars (A-Redonda, B- Coroa, C- Caserta.) germinated in different electrical conductivities of $\mathrm{NaCl}$ solutions.

Although germination speed and seedling development decreased, resulting in a high percentage of underdeveloped, abnormal seedlings and small normal seedlings (Figures 1-3), dead 
seeds were not detected in this experiment. This indicates that salt stress does not kill the seeds of the pumpkin cultivars studied in this work, but only decreases their seedlings development.

Respiration is the first metabolic activity of seeds, concomitant with rehydration. Respiration, which is almost absent in quiescent seeds, rapidly reaches high levels after soaking (CARVALHO; NAKAGAWA, 2012). The respiration rate of seeds is affected by various factors such as humidity, temperature, membrane permeability, oxygen tension, and light (MOUD; MAGHSOUDI, 2012).
In this work, water uptake (imbibition) and respiration were evaluated concomitantly. Imbibition and respiration curves had similar response to optimum and stressful environmental conditions (Figure 4). An excess of soluble salts, which causes a reduction in substrate water potential and a potential toxicity to cells (JALEEL et al., 2007), decreased the pumpkin seeds ability to uptake water from the substrate (Figure $4 \mathrm{~A}, \mathrm{~B}$ ). This in turn, affected the germination speed and percentage of the pumpkin seeds (Figures 1,2).
A
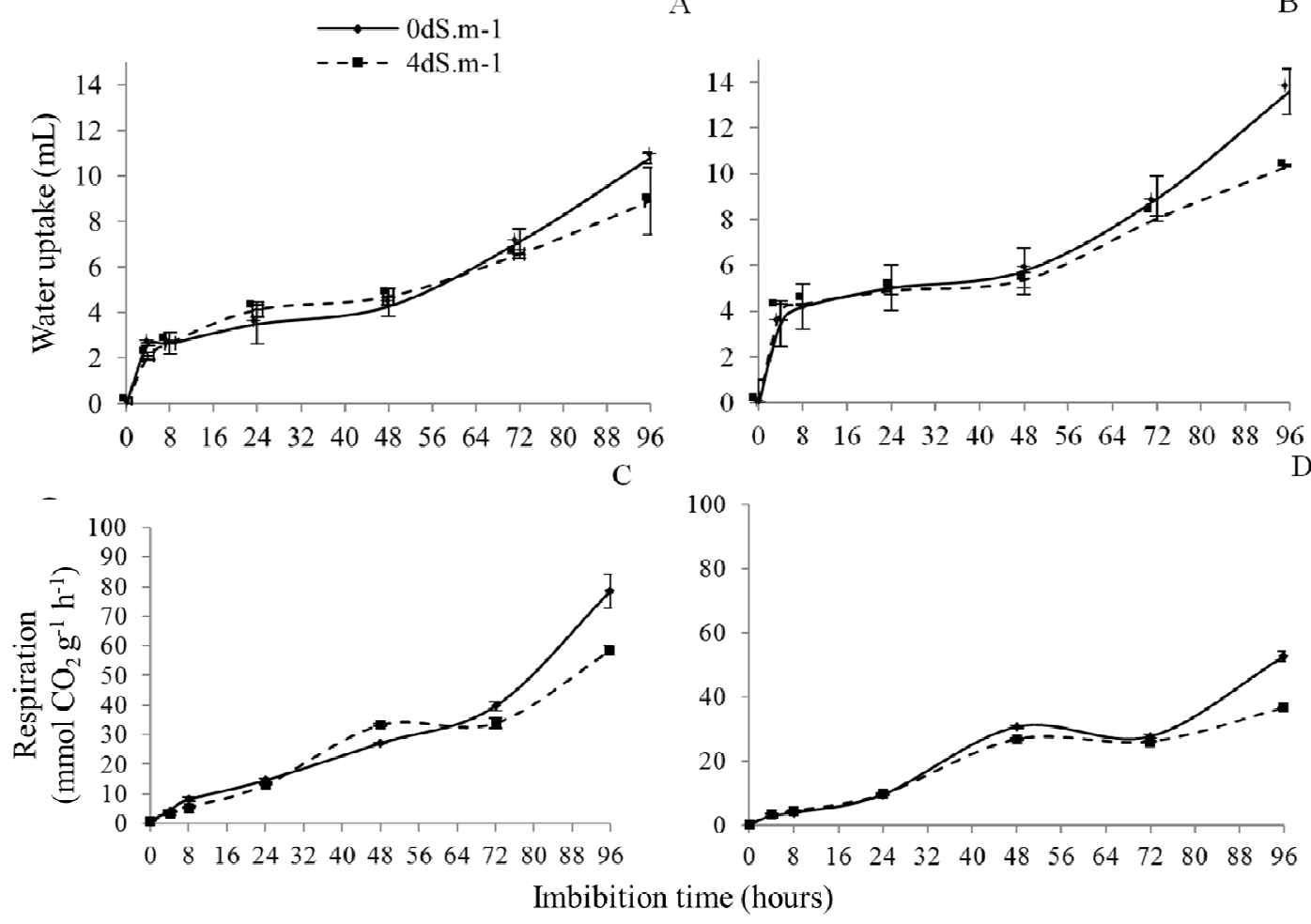

B

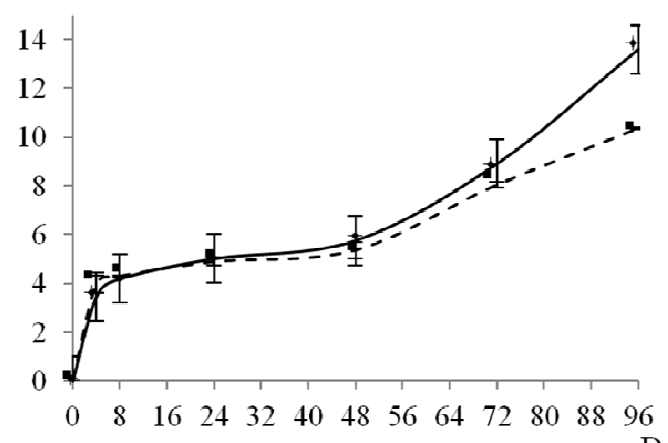

D

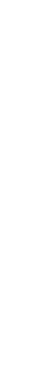

Figure 4. Water uptake and respiration by pumpkin seeds of different cultivars (A, C - Caserta and B, DCoroa) germinating in different electrical conductivities of $\mathrm{NaCl}$ solutions.

The quiescent seeds showed a very low respiration rate, which showed increase during all germination process. Until 24 hours after soaking, which was the time of radicle emergence, there was no difference between the respiration rate of the two cultivars cv. Caserta and cv. Coroa, at both the electrical conductivities levels of 0 and $4 \mathrm{dS} \mathrm{m}^{-1}$ (Figure 4). After 48 hours imbibition, the seedlings of C. pepo cv. Caserta grown in $4 \mathrm{dS} \mathrm{m}^{-1}$ showed higher respiration rate when compared to the ones grown in distilled water $\left(0 \mathrm{dS} \mathrm{m}^{-1}\right.$, Figure $\left.4 \mathrm{C}\right)$. The seedlings of both cultivars grown in salt conditions showed lower respiration after 96 hours of imbibition (Figure 4C, D), than those in distilled water.
Since respiration provides energy for all metabolic activities of the seeds, including radicle emission, reserves degradation, as well as postgermination seedlings development. Its inhibition induces lack of energy for the metabolic and developmental activities of seeds and seedlings (CARVALHO; NAKAGAWA, 2012). For pumpkin cultivars studied in this work, salt stress inhibited respiratory activity after radicular emission (Figure 4), compromising the development of seedlings (Figure 1,3), indicating that salinity prevented the seedlings from obtaining energy necessary its growth and development.

In $\mathrm{NaCl}$ solutions with electrical conductivity of 4 and $6 \mathrm{dS} \mathrm{m} \mathrm{m}^{-1}$, seed germination 
percentage was, respectively, 50 and $20 \%$ in both $C$. pepo cv. Caserta and C. maxima cv. Coroa (Figure 1). Thus, the biochemical changes, such as seed reserves degradation in cotyledons and antioxidant enzymes during the germination were compared in seedlings treated with these solutions (4 and $6 \mathrm{dS} \mathrm{m}^{-}$ ${ }^{1}$ ) and the optimal condition (distilled water), which showed 70 and $60 \%$, respectively in Coroa and Caserta pumpkin cultivars.
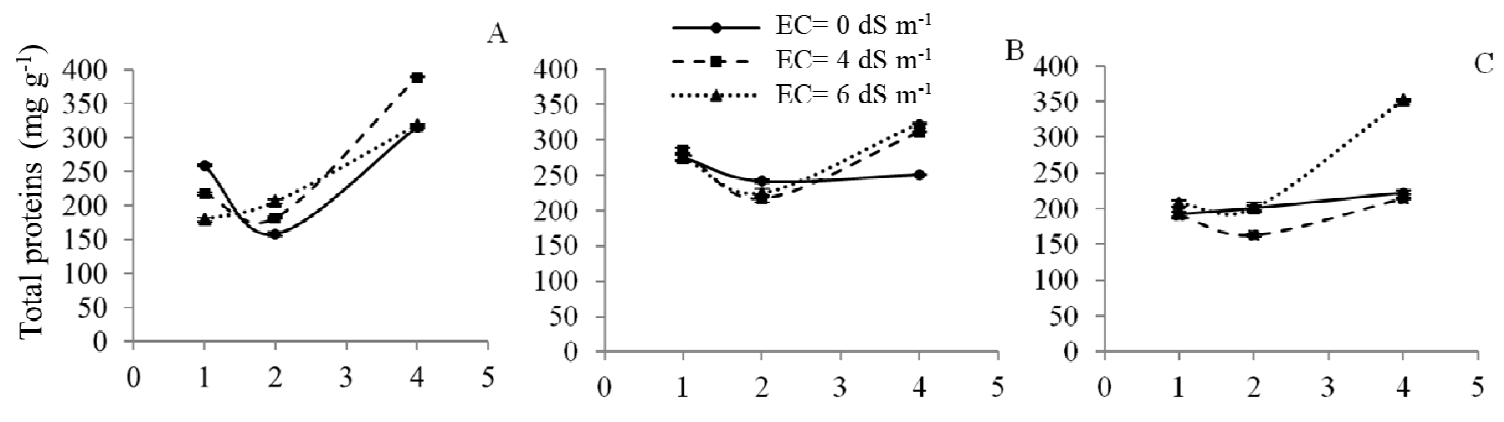

Days after sowing

Figure 5. Total protein content in cotyledons of pumpkin seeds (A- Coroa, B- Caserta and C- Redonda) at one, two and four days after sowing in different electrical conductivities of $\mathrm{NaCl}$ solutions.

The quantification of proteins in the cotyledons of pumpkin seeds showed that the degradation of total soluble proteins occurred until the emergence of radicle, 2 days after sowing (Figure 5). This may comprise hydrolytic enzymes, which are responsible for the degradation of seed reserves, or albumin, an important constituent of the protein reserves in seeds (SILVA; DANTAS, 2016). The transport and mobilization of stored reserves into the developing new tissues of the embryonic axis resumes as of the moment that the radicle emerges (CARVALHO; NAKAGAWA, 2012). The higher protein content observed in pumpkin seeds cotyledons subjected to salt stress compared to those germinated in distilled water (Figure 5) indicated that the translocation of proteins was reduced from the moment the radicles emerged. Besides this, protein synthesis increases in many plants in response to salinity stress, which contributes to cell membrane stabilisation and cell signalling response to salinity (PARIDA; DAS, 2005).

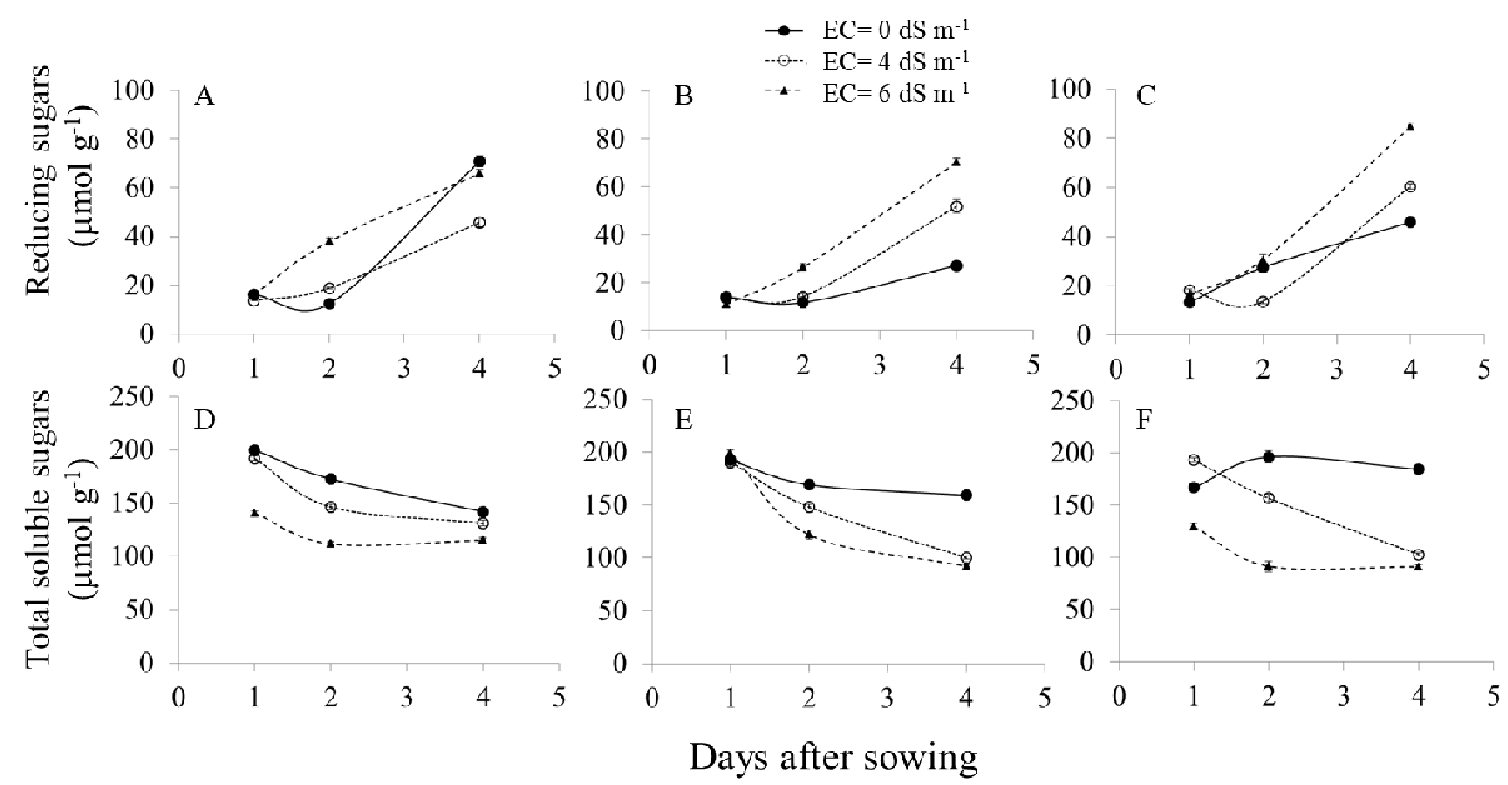

Figure 6. Reducing and total soluble sugars content in cotyledons of pumpkin seeds (A, D- Coroa, B, ECaserta and C, F- Redonda) at one, two and four days after sowing in different electrical conductivities of $\mathrm{NaCl}$ solutions. 
The accumulation of reducing sugars caused by the degradation of total soluble sugars increased in cotyledons of the pumpkin seeds during the germination regardless of the electrical conductivity of the $\mathrm{NaCl}$ solutions. Nevertheless, it was greater in seeds subjected to salt solutions compared to those in seeds germinated in distilled water (Figure 6). Salt stress can increase sugar content in cotyledons in tolerant cultivars in order to decrease the intracellular osmotic potential and maintain the stability of some of the macromolecules, thereby reducing the loss of enzyme activity or membrane integrity (DKHIL; DENDEN, 2010). In species tolerant to this condition, in a preventive way, the regulation of the excess salts of the substrate that would reach the protoplasm takes place and the toxic and osmotic effects associated with the increase of salt concentrations are tolerated (ARZANI, 2008).

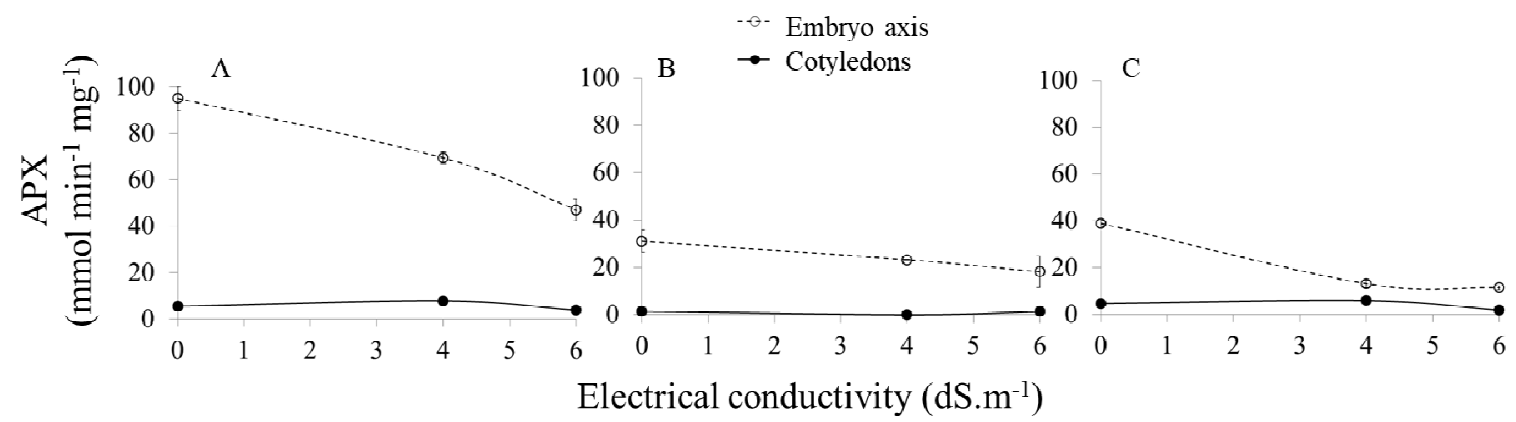

Figure 7. Activity of ascorbate peroxidase (APX) in cotyledons and embryonic axis at four days after sowing pumpkin seeds of different cultivars (A- Coroa, B- Caserta and C- Redonda) in different electrical conductivities of $\mathrm{NaCl}$ solutions.

The seedlings activated an antioxidant defence mechanism due to high oxidative stress by overall alteration in ascorbate peroxidase (APX) and catalase (CAT) activities (Figures 7, 8). The APX activity was reduced in the embryonic axis with increasing electrical conductivity in all cultivars, whilst in cotyledons APX was very low (Figure 7). Ascorbate peroxidase activity has a key role in the ascorbate glutathione cycle and in the elimination of $\mathrm{H}_{2} \mathrm{O}_{2}$ in chloroplasts and the cytosol, and alterations in the activity of this enzyme are strictly correlated with plant's tolerance to oxidative stress (GILL; TUTEJA, 2010). Seeds of cucurbits such as watermelon and cucumber have also shown decrease in APX activity in response to salt stress (MATIAS et al., 2015; DANTAS et al., 2015).

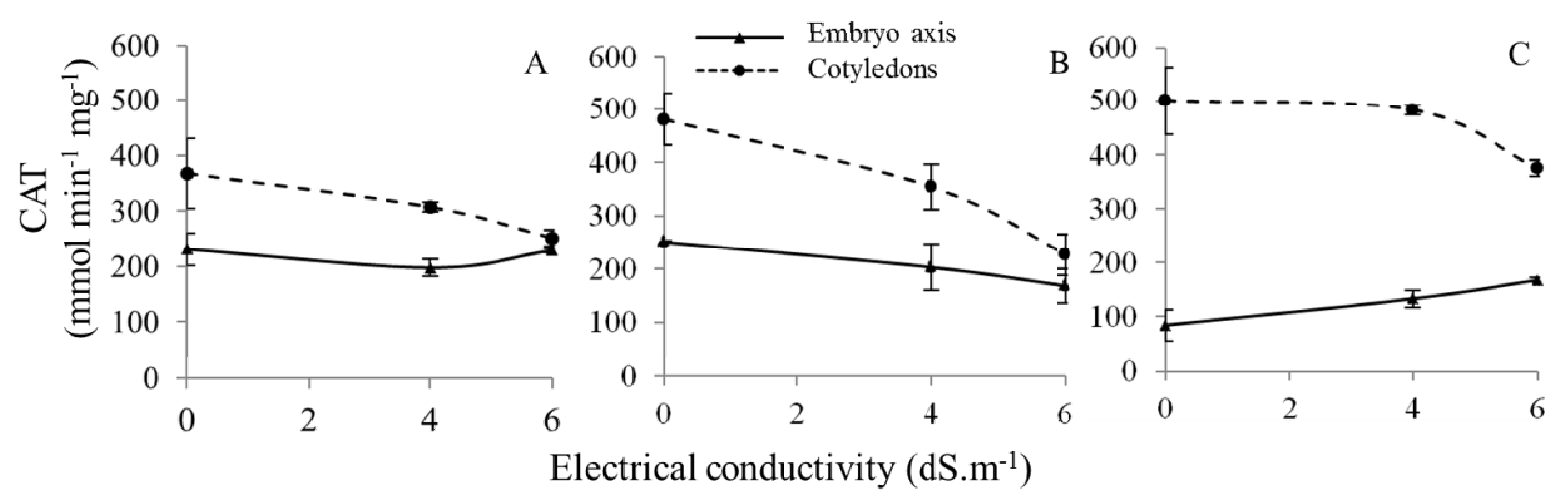

Figure 8. Activity of catalase (CAT) in cotyledons and embryonic axis at four days after sowing pumpkin seeds of different cultivars (A- Coroa , B- Caserta and C- Redonda) in different electrical conductivities of $\mathrm{NaCl}$ solutions.

Catalase activity (CAT) increased in the embryonic axis of the seeds of $C$. pepo cv. Redonda and C. maxima cv. Coroa (Figure 8A, C) with increasing electrical conductivity of the saline solutions, and it was constant in the embryonic axis of C. pepo cv. Caserta (Figure 8B). In contrast, the CAT activity decreased in cotyledons due to the increase of electrical conductivity (Figure 8). Catalases are the principal scavenging enzymes which can directly dismutate $\mathrm{H}_{2} \mathrm{O}_{2}$ and is 
indispensable for ROS detoxification during stress. Environmental stresses can induce either increase or decrease of CAT activity, depending on the intensity, duration, and type (BREUSEGEM et al., 2001) This may occur, because plants have different kind of CAT they respond to environmental stimuli differently (AHMAD et al., 2010). Usually stresses that reduce the rate of protein turnover or degradation (Figure 5) also reduce CAT activity (Figure 8). It is well-known that APX and CAT activity present different mechanisms for metabolising $\mathrm{H}_{2} \mathrm{O}_{2}$ and that these enzymes act in different parts of the cell (ROSA et al., 2010). Although these enzymes degrade the same substrate, they have different affinities for $\mathrm{H}_{2} \mathrm{O}_{2}$ and this specificity may be fundamental to modulate the $\mathrm{H}_{2} \mathrm{O}_{2}$ levels, resulting in signalling and consequently oxidative protection (SCANDALIOS, 2005). Thus, a balance between these enzymes at a biochemical level may be an important mechanism to activate the remaining pathways acting against oxidative stress when a plant faces conditions of environmental stress (NGUYEN et al., 2009).
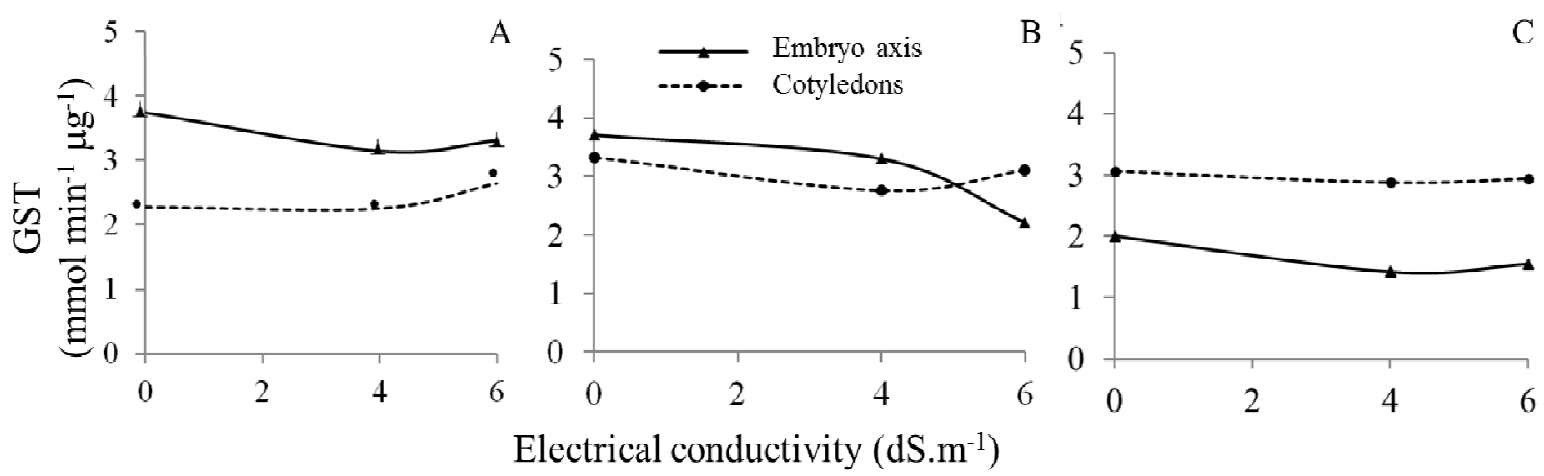

Figure 9. Activity of glutathione - S - transferase (GST) in cotyledons and embryonic axis at four days after sowing pumpkin seeds of different cultivars (A- Coroa , B- Caserta and C- Redonda) in different electrical conductivities of $\mathrm{NaCl}$ solutions.

Glutathione-S-transferases (GSTs) are a group of enzymes found in the cytosol, regulated in vivo by ROS, whose main function is to catalyse the conjugation of reduced glutathione with a wide variety of cytotoxic molecules produced because of oxidative stress (BIBI et al., 2014). The seeds of $C$. pepo cv. Redonda and C. maxima cv. Coroa showed a continuous activity of the GST in both the cotyledons and embryonic axis with increasing electrical conductivity (Figure 9A, C). This may imply, likewise in watermelon cultivars (DANTAS et al., 2015), that none of the cultivars of pumpkin seeds responded to salt stress by detoxifying mechanism by GST.

The presence of ions such as sodium and/or potassium may destabilise the osmotic balance and/or membranes and metabolic processes involved in repair of cell structures (YANG et al., 2008), leading to a drastic reduction of growth and accumulation of dry matter with increasing electrical conductivity, such as those observed in the present work and in other cucurbits (MATIAS et al., 2015; DANTAS et al., 2015). Thus, plant survival depends on the ability to adapt to stress, which acts as a selective pressure, and the factors acting on the tolerance to high salinity levels are frequently dependent on the physiological complexity of the plant (ARZANI, 2008). Plant adaptation and resistance are determined by the changes in plant cell metabolism, such as the synthesis of defence proteins, which are expressed by specific genes. Although specific stress defence proteins were not studied in this work, total soluble protein was increased with increasing stress (Figure 5). These proteins, are usually soluble in the cytosol, have diverse roles in plant resistance and survival and may act by maintaining cellular structure and function (JONES; DANGL, 2006).

The increasing electric conductivity of $\mathrm{NaCl}$ solutions tested in this work altered seeds germination and initial growth of pumpkin seedlings (Figures 1-3). Although all seeds showed radicle protrusion (data not shown), germination speed was decreased by salt (Figure 2). Consequently, the development of seedlings was diminished, producing less normal seedlings and smaller seedlings (Figures 1, 3).

The lower seedling respiration at $4 \mathrm{dS} \mathrm{m}^{-1}$ (Figure 4), inhibits energy production for seed protein and sugar degradation (Figures 5,6) which can also prevent the proper development of seedlings (Figures 1-3). These less vigorous 
pumpkin seedlings will reduce yield by altering plant population density, spatial arrangement, and crop duration, and consequently thus lower economic income (ELLIS, 1992).

In the arid and semiarid climates, irrigation is often essential to achieve economically viable crop productions. The main expected impacts of global warming will be represented by higher and more variable temperatures, changes in precipitation patterns (lower and more erratic rainfall) and higher frequency of extreme events (MARENGO, 2014). Due to the incoming water scarcity, the search for alternatives which aim at better utilization of water resources has become extremely important and along with that studies that can indicate, not only the tolerance, but also the responses of agricultural species and cultivars to environmental stresses.

Although pumpkins are thought to be tolerant to drought and salt stresses because they are widely cropped in the Brazilian Northeast, a semiarid region, this work showed that the seedlings of these species are sensitive to salt stress. In order to enhance stress tolerance, the use of techniques, such osmo and hydropriming (MATIAS et al., 2015) in a short term and genetic breeding programs in a long term, might be important ways to maintain production of pumpkin in regions with poor water quality (ie brackish groundwater) or salinized soil.

\section{CONCLUSIONS}

Salinity did not cause reduction in respiration during germination of pumpkin seeds, affecting only respiration and, thus, vigour of seedlings.

The increase in salinity induced alterations in the degradation of seed sugar and protein reserves in the cotyledons.

Salinity altered the response of ascorbate peroxidase (APX), catalase (CAT) in the embryonic axis of pumpkin seedlings.

The seedlings of pumpkin Cucurbita pepo and $C$. maxima showed low tolerance to salt, which prevented their development into vigorous normal plants.

RESUMO: A salinidade é um dos fatores limitantes para o crescimento das culturas nas regiões áridas e semiáridas. O excesso de sais provoca uma redução no potencial hídrico e causa seca fisiológica e influencia na germinação e crescimento inicial de plântulas Objetivou-se estudar possíveis alterações fisiológicas e metabólicas em sementes e plântulas de abóboras (Cucurbita pepo cultivars Caserta and Redonda and $C$. maxima cv. Coroa), Sendo assim, avaliou-se em sementes e plântulas os parâmetros da germinação (porcentagem e velocidade); crescimento de plântulas; respiração de sementes e plântulas; degradação de açúcar solúveis totais, açúcar redutores e proteínas totais nos cotilédones e atividade das enzimas ascorbato peroxidase (APX), glutationa-S-transferase (GST) e catalase (CAT) durante a germinação e crescimento inicial das cultivares de abóbora em soluções salinas. $\mathrm{O}$ delineamento experimental foi inteiramente casualizado em esquema fatorial $6 \times 3$, com seis condutividades elétricas $\left(0 ; 2 ; 4 ; 6 ; 8\right.$ e $\left.10 \mathrm{dS} . \mathrm{m}^{-1}\right)$ e três cultivares (Redonda, Caserta e Coroa). A salinidade não influenciou a taxa de respiração das sementes durante a germinação, no entanto, a respiração das plântulas diminuiu, assim como o vigor das plântulas. Houve degradação dos açúcares totais e acúmulo de açúcares redutores e proteínas em cotilédones de sementes submetidas a soluções salinas. O aumento da condutividade elétrica induziu redução da atividade de APX no embrião e de CAT nos cotilédones, mas não influenciou GST. Cultivares de aboboras apresentaram baixa tolerância ao estresse salino.

PALAVRAS-CHAVE: Vigor. Plântulas. Condutividade elétrica. Cucurbita pepo. Cucurbita maxima.

\section{REFERENCES}

AHMAD, P.; JALEEL, C. A.; SALEM, M. A.; NABI, G.; SHARMA, S. Roles of enzymatic and non-enzymatic antioxidants in plants during abiotic stress. Critical Reviews in Biotechnology, v. 30, n. 3, p. 161-175, 2010. https://doi.org/10.3109/07388550903524243

ARAGÃO, C. A.; SANTOS, J. S.; QUEIROZ, S. O. P.; DANTAS, B. F. Avaliação de cultivares de melão sob condições de estresse salino. Revista Caatinga, v. 22, n. 2, p. 161-169, 2009.

ARZANI, A. Improving salinity tolerance in crop plants: a biotechnological view. In Vitro Cellular \& Developmental Biology-Plant, v. 44, n. 5, p. 373-383, 2008. https://doi.org/10.1007/s11627-008-9157-7 
BIBI, N.; YUAN, S.; ZHU, Y.; WANG, X. Improvements of fertility restoration in cytoplasmic male sterile cotton by enhanced expression of glutathione- S- transferase (GST) gene. Journal of Plant Growth Regulation, v. 33, n. 2, p. 420-429, 2014. https://doi.org/10.1007/s00344-013-9393-x

BRASIL. Ministério da Agricultura, Pecuária e Abastecimento. Regras para análise de sementes. Ministério da Agricultura, Pecuária e Abastecimento. Secretaria de Defesa Agropecuária. Brasília: MAPA/ACS, 2009. $395 \mathrm{p}$.

BREUSEGEM, F. V.; VRANOVÁ, E.; DAT, J. F.; INZÉ, D. The role of active oxygen species in plant signal transduction. Plant Science, v. 161, n. 3, p. 405-414, 2001. https://doi.org/10.1016/S0168-9452(01)00452-6

CARVALHO, N. M.; NAKAGAWA, J. Sementes: Ciência, tecnologia e produção. 4.ed. Jaboticabal: UNESP, 2012. 590p.

CAVERZAN, A.; PASSAIA, G.; ROSA S. B.; RIBEIRO, C. W.; LAZZAROTTO, F.; MARGIS-PINHEIRO, M. Plant responses to stresses: Role of ascorbate peroxidase in the antioxidant protection. Genetics and Molecular Biology, v. 35, n. 4, p. 1011-1019, 2012. https://doi.org/10.1590/S1415-47572012000600016

DANTAS, B. F.; SILVA, R. de C. B. da; RIBEIRO, R. C.; ARAGÃO, C. A. Respiration and antioxidant enzymes activity in watermelon seeds and seedlings subjected to salt and temperature stresses. American Journal of Experimental Agriculture, v. 7, n. 2, p. 70-77, 2015. https://doi.org/10.9734/AJEA/2015/15749

DKHIL, B. B.; DENDEN, M. Salt stress induced changes in germination, sugars, starch and enzyme of carbohydrate metabolism in Abelmoschus esculentus (L.) Moench seeds. African Journal of Agricultural Research, v. 5, n. 12, p. 1412-1418, 2010.

ELLIS, R. H. Seed and seedling vigour in relation to crop growth and yield. Plant Growth Regulation, v. 11, n. 1, p 249-255, 1992. https://doi.org/10.1007/BF00024563

FARAHANI, H. A.; MAROUFI, K. Effect of hydropriming on seedling vigour in basil (Ocimum basilicum L.) under salinity conditions. Advances in Environmental Biology, v. 5, n. 8, p. 828-833, 2011.

FERREIRA, M. A. J.; MELO, A. M. T.; CARMO, C. A. S.; SILVA, D. J. H.; LOPES, J. F.; QUEIROZ, M. A.; MOURA, M. C. C. L.; DIAS, R. C. S.; BARBIERI, R. L.; BARROZO, L. V.; GONÇALVES, E. M.;

NEGRINI, A. C. A. Mapeamento da distribuição geográfica e conservação dos parentes silvestres e variedades crioulas de Cucurbita. In: Parentes Silvestres das espécies de plantas cultivadas. Secretaria de Biodiversidade e Florestas. Brasília, 2006. 44p.

GILL, S. S.; TUTEJA, N. Reactive oxygen species and antioxidant machinery in abiotic stress tolerance in crop plants. Plant physiology and biochemistry, v. 48, n. 12, p. 909-930, 2010.

https://doi.org/10.1016/j.plaphy.2010.08.016

JALEEL, C. A.; GOPI, R.; SANKAR, B.; MANIVANNAN, P.; KISHOREKUMAR, A.; SRIDHARAN, R.; PANNEERSELVAM, R. Studies on germination, seedling vigour, lipid peroxidation and proline metabolism in Catharanthus roseus seedlings under salt stress. South African Journal of Botany, v. 73, n. 2, p. 190-195, 2007. https://doi.org/10.1016/j.sajb.2006.11.001

JONES, J. D.; DANGL, J. L. The plant immune system. Nature, v. 444, n. 3, p. 323-329, 2006. https://doi.org/10.1038/nature05286

LI, T.; HU, Y.; DU, X.; TANG, H.; SHEN, C.; WU, J. Salicylic acid alleviates the adverse effects of salt stress in Torreya grandis cv. Merrillii seedlings by activating photosynthesis and enhancing antioxidant systems.

PloS one, v. 9, n. 10, 2014. https://doi.org/10.1371/journal.pone.0109492 
MARENGO, J. A. O Futuro Clima do Brasil. Revista USP, n.103, p. 25-32, 2014.

https://doi.org/10.11606/issn.2316-9036.v0i103p25-32

MATIAS, J. R.; RIBEIRO, R. C.; ARAGÃO. C. A.; ARAUJO, G. G. L.; DANTAS, B. F. Physiological changes in osmo and hydroprimed cucumber seeds germinated in biosaline water. Journal of Seed Science, $v$. 37, n. 1, p. 7-15, 2015. https://doi.org/10.1590/2317-1545v37n1135472

MOHAMMAD, I. G. R.; AMIR, I. F. The effect of priming on seed performance of canola (Brassica napus L.) under drought stress. American Eurasian Journal of Agricultural \& Environmental Sciences, v. 2, n. 9, p. 202-207, 2010.

MOUD, A. M.; MAGHSOUDI, K. Salt stress effects on respiration and growth of germinated seeds of different wheat (Triticum aestivum L.) cultivars. World Journal of Agricultural Sciences, v. 4, n. 3, p. 351-358, 2008.

NGUYEN, G. N.; HAILSTONES, D. L. M.; WILKES, M.; SUTTON, B. G. Drought-induced oxidative conditions in rice anthers leading to a programmed cell death and pollen abortion. Journal of Agronomy \& Crop Science, v. 195, n. 3, p. 157-164, 2009. https://doi.org/10.1111/j.1439-037X.2008.00357.x

PARIDA, A. K.; DAS, A. B. Salt tolerance and salinity effects on plants: a review. Ecotoxicology and Environmental Safety, v. 60, n. 2, p. 324-49. 2005. https://doi.org/10.1016/j.ecoenv.2004.06.010

RANAL, M. A.; SANTANA, D. G. How and why to measure the germination process? Revista Brasileira de Botânica, v. 29, n. 1, p. 1-11, 2006. https://doi.org/10.1590/S0100-84042006000100002

RESENDE, G. M.; BORGES, R. M. E.; GONÇALVES, N. P. S. Produtividade da cultura da abóbora em diferentes densidades de plantio no Vale do São Francisco. Horticultura Brasileira, v. 31, n. 3, p. 504-508, 2013. https://doi.org/10.1590/S0102-05362013000300027

RIBEIRO, R. C.; DANTAS, B. F.; PELACANI, C. R. Mobilization of reserves and germination of seeds of Erythrina velutina Willd. (Leguminosae - Papilionoideae) under different osmotic potentials. Revista Brasileira de Sementes, v. 34, n. 4, p. 580-588, 2012. https://doi.org/10.1590/S0101-31222012000400008

RIBEIRO, R. C.; MATIAS, J. R.; PELACANI, C. R.; DANTAS, B. F. Activity of antioxidant enzymes and proline accumulation in Erythrina velutina Willd. seeds subjected to abiotic stresses during germination. Journal of Seed Science, v. 36, n. 2, p. 231-239, 2014. https://doi.org/10.1590/2317-1545v32n2956

RICHARDS, L.A. Suelos salinos y sodicos: diagnostico y rehabilitacion. 6. ed. México: Limusa, 1974. 172p.

ROSA, S. B.; CAVERZAN, A.; TEIXEIRA, F. K.; LAZZAROTTO, F.; SILVEIRA, J. A.; FERREIRASILVA, S. L.; ABREU-NETO, J.; MARGIS, R.; MARGIS-PINHEIRO, M. Cytosolic APX knockdown indicates an ambiguous redox responses in rice. Phytochemistry, v. 71, n. 6, p. 548-558, 2010.

https://doi.org/10.1016/j.phytochem.2010.01.003

SCANDALIOS, J. G. Oxidative stress: Molecular perception and transduction of signals triggering antioxidant gene defenses. Brazilian Journal of Medical and Biological Research, v. 38, n. 7, p. 995-1014, 2005. https://doi.org/10.1590/S0100-879X2005000700003

SECCO, L. B.; QUEIROZ, S. O.; DANTAS, B. F.; SOUZA, Y. A.; SILVA, P. P. Germinação de sementes de melão (Cucumis melo L.) em condições de estresse salino. Revista Verde de Agroecologia e Desenvolvimento Sustentável, v. 4, n. 4, p. 129-135, 2010.

SECKIN, B.; TURKAN, I.; SEKMEN, A. H.; OZFIDAN, C. The role of antioxidant defense systems at differential salt tolerance of Hordeum marinum Huds. (sea barley grass) and Hordeum vulgare L. (cultivated barley). Environmental and Experimental Botany, v. 69, n. 1, p. 76-85, 2010.

https://doi.org/10.1016/j.envexpbot.2010.02.013 
SILVA, F. F. S.; DANTAS, B. F. Quantification of storage proteins during seed imbibition of native species from the brazilian Caatinga vegetation. Semina. Ciências Agrárias, v. 37, n. 4, p. 1733-1744, 2016. https://doi.org/10.5433/1679-0359.2016v37n4p1733

SILVA, J. E. S. B.; MATIAS, J. R.; GUIRRA, K. S.; ARAGÃO, C. A.; ARAUJO, G. G. L.; DANTAS, B. F. Development of seedlings of watermelon cv. Crimson Sweet irrigated with biosaline water. Revista Brasileira de Engenharia Agrícola e Ambiental, v. 19, n. 9, p. 835-840, 2015. https://doi.org/10.1590/18071929/agriambi.v19n9p835-840

SOLTANI, A.; GHOLIPOOR, M.; ZEINALI, E. Seed reserve utilization and seedling growth of wheat as affected by drought and salinity. Environmental and Experimental Botany, v. 55, n. 01/02, p. 195-200, 2006. https://doi.org/10.1016/j.envexpbot.2004.10.012

TORRES, S. B. Germinação e desenvolvimento de plântulas de melancia em função da salinidade. Revista Brasileira de Sementes, v. 29, n. 3, p. 77-82, 2007. https://doi.org/10.1590/S0101-31222007000300010

TUTEJA, N.; AHMAD, P.; PANDA, B. B.; TUTEJA, R. Genotoxic stress in plants: shedding light on DNA damage, repair and DNA repair helicases. Mutation Research, v. 681, p. 134-149, 2009

https://doi.org/10.1016/j.mrrev.2008.06.004

YANG, C.; SHI, D.; WANG, D. Comparative effects of salt and alkali stresses on growth, osmotic adjustment and ionic balance of an alkali-resistant halophyte Suaeda glauca (Bge.). Plant Growth Regulation, v. 56, n. 2, 2008. https://doi.org/10.1007/s10725-008-9299-y 